\title{
Acoustic and seismic imaging of the Adra Fault (NE Alboran Sea): in search of the source of the 1910 Adra earthquake
}

\author{
E. Gràcia ${ }^{1,2}$, R. Bartolome ${ }^{1,2}$, C. Lo Iacono ${ }^{1,2}$, X. Moreno ${ }^{1,3}$, D. Stich ${ }^{4}$, J. J. Martínez-Diaz ${ }^{5}$, G. Bozzano ${ }^{6}$, \\ S. Martínez-Loriente ${ }^{1,2}$, H. Perea ${ }^{1,2}$, S. Diez ${ }^{1}$, E. Masana ${ }^{3}$, J. J. Dañobeitia ${ }^{1,2}$, O. Tello ${ }^{7}$, J. L. Sanz ${ }^{7}$, E. Carreño ${ }^{8}$, and \\ EVENT-SHELF Team* \\ ${ }^{1}$ Unitat de Tecnologia Marina - CSIC, CMIMA, Pg. Marítim de la Barceloneta 37-49, 08003 Barcelona, Spain \\ ${ }^{2}$ Institut de Ciències del Mar - CSIC, CMIMA, Pg. Marítim de la Barceloneta 37-49, 08003 Barcelona, Spain \\ ${ }^{3}$ RISKNAT, Dpt. Geodinàmica i Geofísica, Universitat de Barcelona, Martí i Franquès s/n, 08028 Barcelona, Spain \\ ${ }^{4}$ Instituto Andaluz de Geofísica (IAG), Univ. Granada, 18071 Granada, Spain \\ ${ }^{5}$ Instituto de Geociencias UCM, CSIC, Dpto. Geodinámica, Facultad de Ciencias Geológicas, Universidad Complutense, \\ 28004 Madrid, Spain \\ ${ }^{6}$ Servicio de Hidrografía Naval, Av. Montes de Oca 2124, C1270ABV Buenos Aires, Argentina \\ ${ }^{7}$ Instituto Español de Oceanografía, Corazón de María 8, 28002 Madrid, Spain \\ ${ }^{8}$ Red Sísmica Nacional, Instituto Geográfico Nacional, c/ General Ibáñez Ibero, 3, 28003 Madrid, Spain \\ *M. Farran (ICM-CSIC), E. Andara (IGME), S. Pérez and M. J. Román Alpiste (UG) \\ Correspondence to: E. Gràcia (egracia@cmima.csic.es)
}

Received: 21 March 2012 - Revised: 19 July 2012 - Accepted: 9 August 2012 - Published: 7 November 2012

\begin{abstract}
Recently acquired swath-bathymetry data and high-resolution seismic reflection profiles offshore Adra (Almería, Spain) reveal the surficial expression of a NWSE trending $20 \mathrm{~km}$-long fault, which we termed the Adra Fault. Seismic imaging across the structure depicts a subvertical fault reaching the seafloor surface and slightly dipping to the NE showing an along-axis structural variability. Our new data suggest normal displacement of the uppermost units with probably a lateral component. Radiocarbon dating of a gravity core located in the area indicates that seafloor sediments are of Holocene age, suggesting present-day tectonic activity. The NE Alboran Sea area is characterized by significant low-magnitude earthquakes and by historical records of moderate magnitude, such as the $M_{\mathrm{w}}=6.11910$ Adra Earthquake. The location, dimension and kinematics of the Adra Fault agree with the fault solution and magnitude of the 1910 Adra Earthquake, whose moment tensor analysis indicates normal-dextral motion. The fault seismic parameters indicate that the Adra Fault is a potential source of large magnitude $\left(M_{\mathrm{w}} \leq 6.5\right)$ earthquakes, which represents an unreported seismic hazard for the neighbouring coastal areas.
\end{abstract}

\section{Introduction}

Seismogenic faults may be silent in the instrumental and historical periods and, therefore, their seismic potential may remain inadvertently hidden. In very active areas it has been demonstrated that a paleoseismological analysis can detect and characterize the seismic potential of these faults (e.g. Wallace, 1981; Pantosti and Yeats, 1993; McCalpin, 1996). Nevertheless, slow-moving faults capable of generating large-magnitude earthquakes with long recurrence intervals $(>1000 \mathrm{yr})$ also deserve special attention. In recent years, a continuous effort has been made to adapt the paleoseismological approach to the slow active faults of the southeastern Iberian margin that accommodate the convergence between the Iberian and African plates (e.g. Martínez-Diaz et al., 2001; Martínez-Díaz and Hernández-Enrile, 2004; Masana et al., 2004, 2005; Gràcia et al., 2006, 2010; Moreno et al., 2008). This approach, which also considers the offshore faults, is crucial for estimating realistic values of the seismic hazard in this area largely based on the relatively short period of instrumental $(<100 \mathrm{yr})$ and historical $(<2000 \mathrm{yr})$ earthquake catalogues for the Iberian Peninsula (e.g. Peláez and López Casado, 2002). 


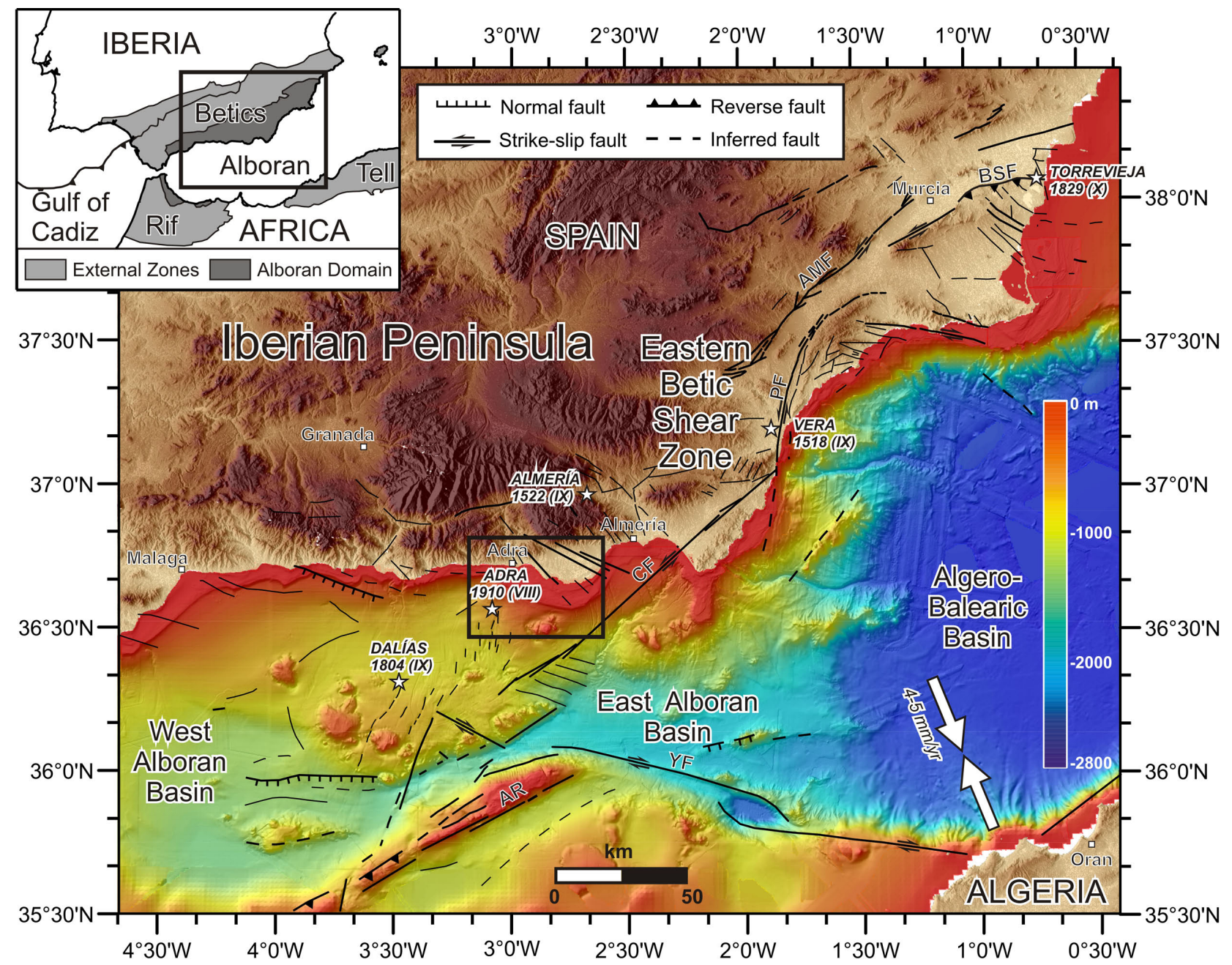

Fig. 1. Regional topographic and bathymetric map of the southeast Iberian margin constructed from digital grids released by SRTM-3, IEO bathymetry (Ballesteros et al., 2008; Muñoz et al., 2008) and MEDIMAP multibeam compilation (MediMap et al., 2008) at 90 m grid-size. Epicenters of the largest historical earthquakes (MSK Intensity > VIII) in the region are depicted by a white star (I.G.N., 2010). Grey arrows pointing opposite each other show the direction of convergence between the Eurasian and African plates from NUVEL1 model (DeMets et al., 2010). The black outlined rectangle depicts the study area presented in Fig. 2. BSF: Bajo Segura Fault; AMF: Alhama de Murcia Fault, PF: Palomares Fault, CF: Carboneras Fault, YF: Yusuf Fault, AR: Alboran Ridge. Inset: Plate tectonic setting and main geodynamic domains of the south Iberian margin along the boundary between the Eurasian and African Plates.

The present-day crustal deformation of the southeastern Iberian margin, which includes the Iberian Peninsula and adjacent offshore Mediterranean region, is driven mainly by the NW-SE convergence $\left(4.5-5.6 \mathrm{~mm} \mathrm{yr}^{-1}\right)$ between the African and Eurasian plates (e.g. Argus et al., 1989; DeMets et al., 2010) (Fig. 1). This convergence is accommodated over a wide deformation zone with significant seismicity south of the Iberian Peninsula (e.g. Buforn et al., 2004; Stich et al., 2003a, 2006, 2010). Quaternary faulting activity is dominated by a large left-lateral strike-slip system referred to as the Eastern Betic Shear Zone (EBSZ) (e.g. Bousquet, 1979; Sanz de Galdeano, 1990; Silva et al., 1993). This active fault system runs along more than $450 \mathrm{~km}$, and its terminal splays (i.e. the Bajo Segura Fault to the northeast and the Carboneras Fault to the southwest) extend into the sea (Comas et al., 1999; Alfaro et al., 2002; Gràcia et al., 2006; Moreno et al., 2008; Moreno, 2011; Perea et al., 2012) (Fig. 1). In the SE Iberian margin, instrumental seismicity is characterized by continuous, shallow seismic events of low to moderate magnitude $\left(M_{\mathrm{w}}<5.5\right)$ (Buforn et al., 1995, 2004; Stich et al., 2003a, 2006, 2010). Nevertheless, large destructive earthquakes (MSK Intensity IX-X) have occurred in the region, as revealed by historical records (I.G.N., 2010) (Fig. 1). They may represent a significant earthquake and tsunami hazard along the Iberian Peninsula and North African coasts.

In this paper, we focus on the area located to the west of the Carboneras Fault, in the Adra-Almería margin in 
the northern Alboran Sea (Fig. 1). This area demonstrated recent seismic activity with most of the epicentres located offshore, especially during the 1993-1994 earthquake series (up to $M_{\mathrm{w}}=4.9$ ) (Stich et al., 2001). In addition, this area includes the submarine epicentral zone of the Adra historical earthquake in 1910 with an estimated $M_{\mathrm{w}}=6.1$ (Stich et al., 2003b) (Fig. 1). The neotectonics of the structures located onshore (e.g. Campo de Dalías in the Almería province, SE Spain) has been studied in detail (e.g. Martínez-Díaz and Hernández-Enrile, 2004; Marín-Lechado et al., 2005, 2007; Pedrera et al., 2012) (Fig. 2). However, little is known about the structures located offshore. To investigate the active tectonic sources in the Almería margin offshore Adra (Spain) we carried out the EVENT-SHELF high-resolution seismic survey (Figs. 1, 2, 3). The main objectives of this study are (a) to describe the seafloor morphology of the area, (b) to characterize the shallow structure and kinematics of the largest fault newly recognized, the Adra Fault, and (c) to find out whether the Adra Fault is the tectonic source of the historically recorded 1910 Earthquake.

\section{Tectonics and seismicity of the Adra-Almería margin}

The study area is located in the Adra-Almería margin, corresponding to the Betic internal zones or Alboran Domain (Figs. 1 and 2). Onshore, this area includes the Contraviesa and Gádor Ranges constituted by the Alpujarride metamorphic complex, basement of the Neogene to Quaternary sediments of the Campo de Dalías, where recent deformation has been recognized (e.g. Martínez-Díaz and Hernández-Enrile, 2004; Marín-Lechado et al., 2005; Pedrera et al., 2012) (Fig. 2). The largest faults in the Campo de Dalías are the Loma del Viento, Balanegra and Punta Entinas faults, the last two controlling several $\mathrm{km}$-long linear segments of the coastline. They are NW-SE striking normal faults forming halfgraben structures, such as the Puente del Rio Fault (MartínezDíaz and Hernández-Enrile, 2004) (Fig. 2a), although the Loma del Viento fault has a certain dextral component affecting the Quaternary deposits (Pedrera et al., 2012). In the Campo de Dalías, near the Loma del Viento Fault, Pleistocene raised marine terraces are present, forming a staircase of 16 terraces that reaches $82 \mathrm{~m}$ a.s.l. (Zazo et al., 2003). These terraces provide information about recent uplift of the region with maximum values of $0.046 \mathrm{~m} \mathrm{ka}^{-1}$ over the last $130 \mathrm{ka}$ for the up-thrown block of the Loma del Viento (Zazo et al., 2003; Marín-Lechado et al., 2005) (Fig. 2). On the basis of pre-existing offshore commercial multichannel seismic reflection profiles from the Almería shelf, several authors suggest the presence of NW-SE trending faults and open, gentle folds extending up to $100 \mathrm{~km}$ in length in the offshore area (Rodríguez-Fernández and Martín-Penela, 1993; Martínez-Díaz and Hernández-Enrile, 2004; Marín-Lechado et al., 2005, 2007; Pedrera et al., 2012).
In regards to instrumental seismicity, the most intense seismic period recently recorded in this area occurred during 1993-1995, where several multiplets of up to magnitude $M_{\mathrm{w}}=4.9$ occurred near Adra (Stich et al., 2001) and produced significant damage in the Berja and Adra areas. Since then, the seismic crisis of July/August $1997\left(M_{\mathrm{w}} \leq 4.5\right.$, Stich et al., 2003a), October/November $2008\left(M_{\mathrm{w}} \leq 4.4\right.$, Stich et al., 2010) and more recently November $2010\left(M_{\mathrm{w}} \leq 4.2\right)$ demonstrates the continuous seismicity nucleated around Campo de Dalías, which is of shallow depth (Pedrera et al., 2012). However, historical and archaeological records suggest that the Adra-Almería region has been affected by at least 50 destructive earthquakes (MSK Intensity > VIII) over the past $2000 \mathrm{yr}$ (e.g. Marín-Lechado et al., 2005), providing evidence of a significant seismic hazard. The town of Almería was devastated by earthquakes in 1487, 1522 $\left(\mathrm{I}_{0}=\mathrm{IX}\right.$ MSK) and 1658 ( $\mathrm{I}_{0}=$ VIII MSK). In 1804, a long period of seismic activity (up to $\mathrm{I}_{0}=\mathrm{IX}$ MSK) affected Adra and nearby areas (e.g. Marín-Lechado et al., 2005). These events have been mainly attributed to the motion along the Carboneras fault system (Keller et al., 1995). On the other hand, it has been suggested that the 1910 Adra Earthquake $\left(M_{\mathrm{W}}=6.1, \mathrm{I}_{0}=\right.$ VIII MSK in Adra) was probably generated by N120-N130 trending faults offshore (Stich et al., 2003b), although, the tectonic source of this earthquake is still unknown. Searching for the source of this earthquake is the aim of the present study.

\section{Data and methods}

Fault exploration of active regions offshore integrates the most advanced technologies covering different scales of resolution (e.g. Bartolome et al., 2009). Acoustic mapping techniques, such as swath-bathymetry, allow us to identify the geomorphological evidence of active faults, such as seafloor ruptures, fault scarps and fault traces. Seismic imaging methods, especially high-resolution, enable us to detect the stratigraphic evidence of past seismic activity, such as upward decreasingly displaced seismic horizons, folded and faulted reflectors, zones of shearing and discontinuities. Sediment sampling methods and subsequent analyses allow us to characterize and date mass transport deposits triggered during seismic events, and to shed light on the nature and age of the most recent sediments.

The present study results from an integration of different types of data acquired: swath-bathymetry, singlechannel Sparker seismics and sediment cores. The data were acquired during the IMPULS (May-June 2006) and EVENT-SHELF (September 2008) cruises on board the Spanish R/V Hespérides and R/V García del Cid, respectively. The bathymetric data used for this work correspond to a multibeam compilation including data from different echosounders: Simrad EM300 data from the Spanish Institute of Oceanography (Muñoz et al., 2008) completed with 

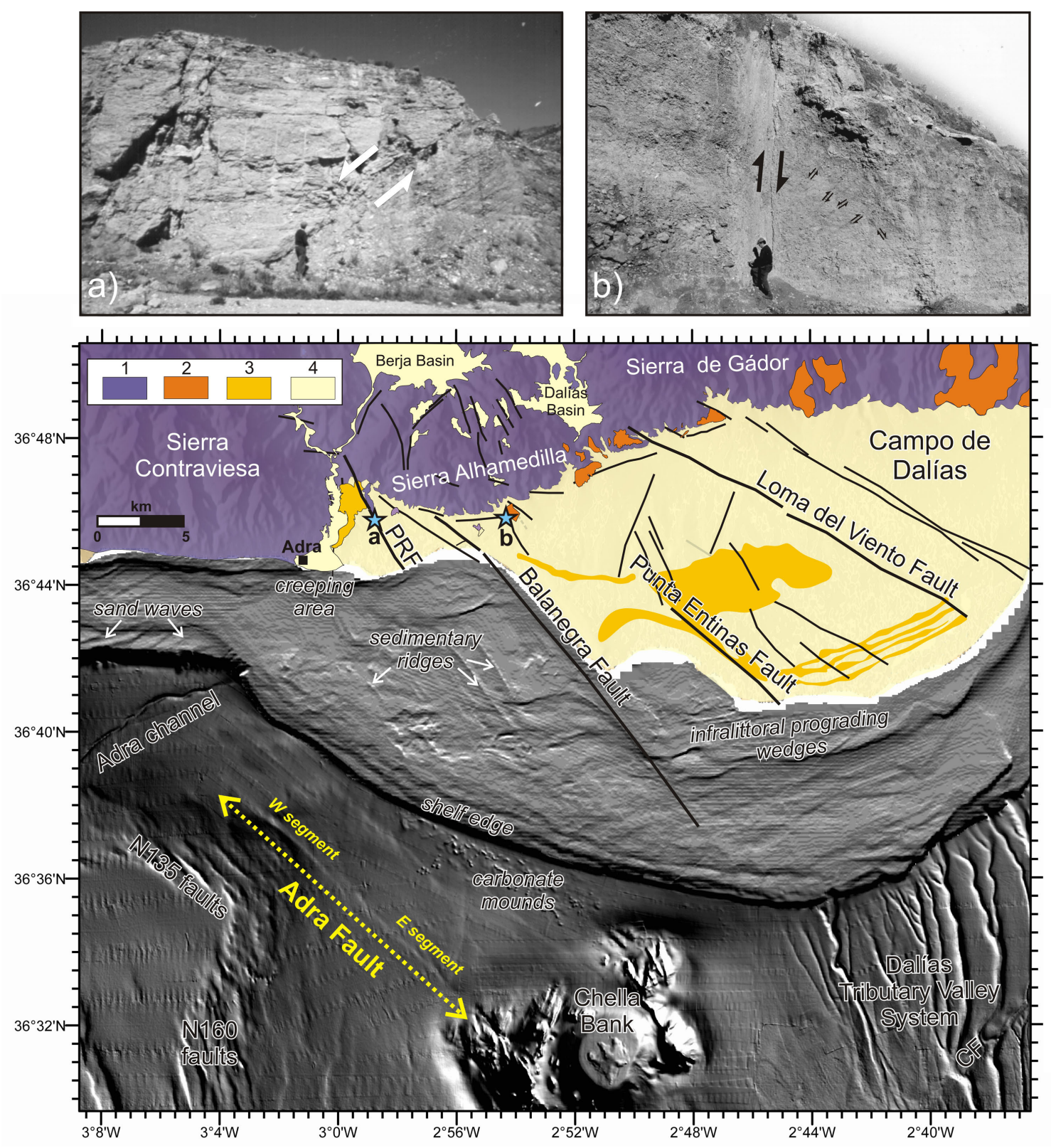

Fig. 2. Shaded relief bathymetric map of the Adra-Almería margin. The Adra Fault and segments are marked in yellow. Onshore, main structures and geological units are also depicted. They correspond to 1: Alboran Domain basement; 2: Upper Miocene deposits; 3: Pliocene deposits; and 4: Quaternary deposits (modified from Martínez-Díaz, 1998; Sanz et al., 2004; Marín Lechado et al., 2005; Fernández-Salas et al., 2009; Pedrera et al., 2012). PRF: Puente del Río Fault; CF: Carboneras Fault. Blue stars depict location of pictures from insets. Insets: Field examples of normal faults from the Adra-Campo de Dalías region. (a) The N155 Puente del Río normal fault separating the deltaic Pliocene deposits from the grey Paleozoic phyllites on the footwall. (b) A N170 trending normal fault cutting a Pleistocene alluvial fan on the southern slope of Sierra Alhamedilla. The striae show pitch of $110^{\circ}$ and dextral component (modified from Martínez-Díaz, 1998).

the Simrad EM12S data acquired during the IMPULS cruise, and $180 \mathrm{kHz}$ Elac Nautik SeaBeam 1050D data acquired during the EVENT-SHELF cruise (Fig. 2). Digital terrain models at $70 \mathrm{~m}$ and $20 \mathrm{~m}$ grid size were obtained using HIPSCARIS and Caraibes-TD softwares (IFREMER, France) and slope maps were generated with ArcGIS (Figs. 2 and 3).
A high-resolution single-channel system was used during the EVENT-SHELF cruise to investigate the offshore continuation of the structures of Campo de Dalías in the continental shelf and upper slope. The source, triggered every $2 \mathrm{~s}$, was a Sparker $6 \mathrm{~kJ}$ GEO-SPARK specially designed to favour high frequencies. The power of the source ranged from 4 to $6 \mathrm{~kJ}$ according to the seafloor depth. The 


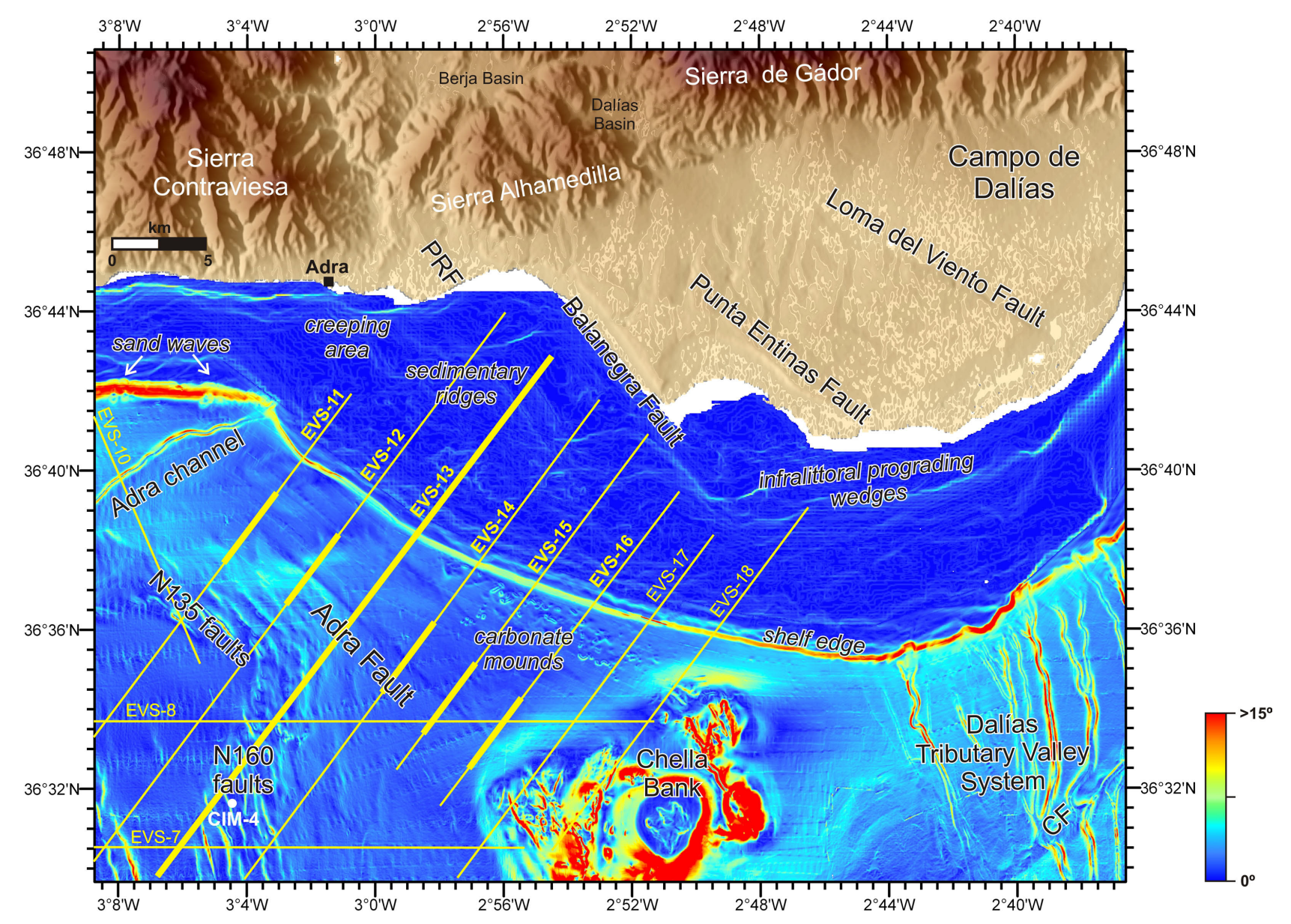

Fig. 3. Slope map of the Adra-Almería shelf and upper slope with the location of the main features (illumination from the NE, scale in degrees). Sparker profiles acquired during the EVENT-SHELF cruise across the Adra Fault are depicted by yellow lines. Thicker yellow lines correspond to profiles presented in Figs. 4 and 6. White dot locates core CIM-4 presented in Fig. 5. PRF: Puente del Río Fault; CF: Carboneras Fault.

$4 \mathrm{~kJ}$ source was used for depths below $150 \mathrm{~m}$, whereas the $6 \mathrm{~kJ}$ was adopted for the deeper areas. The receiver consisted of a $9 \mathrm{~m}$ long, 24-hydrophone single-channel streamer. The sampling rate was $100 \mu$ s with a record length of $1.5-2.0 \mathrm{~s}$ TWTT (two-way travel time). Processing was carried out using the software Geotrace. The processing flow included change in data polarity, debiasing, a minimum bandpass filter $(350-1500 \mathrm{~Hz})$, AGC $(10 \mathrm{~ms}$ window), gain $(1-3 \mathrm{~dB})$ and spherical divergence, and swell filter. Data were exported to SEG-Y format and integrated in the SMT Kingdom Suite software. A total of 11 Sparker profiles (referred to as EVS7, EVS-8 and EVS-10 to EVS-18) were acquired in the study area (Fig. 3). Most of the profiles, which ran from the shelf to the mid-slope, were oriented NE-SW, perpendicular to the main fault orientation on land. Best results were achieved in flat areas with highly penetrative sediments, while abrupt slope areas and volcanic outcrops displayed very low penetration (Fig. 4). Seismic visualisation and interpretation were carried out using the SMT Kingdom Suite software.
A total of seven sediment cores were collected in the Almería margin. Particular reference is made here to CIM-4, a $2 \mathrm{~m}$ long gravity core collected during the IMPULS cruise on the Adra slope at about $850 \mathrm{~m}$ depth (Figs. 3 and 5). Immediately after core splitting and cleaning, the whole core was imaged with digital colour photo and logged for physical properties at $2 \mathrm{~cm}$ intervals using the GEOTEK multisensor core-logger. Sediment physical property measurements included magnetic susceptibility, P-wave velocity and gamma-ray attenuation from which density is calculated. Lightness $(L *)$ was measured every $2 \mathrm{~cm}$ using a Minolta spectrophotometer. Detailed core description was based on changes observed in the colour, lithology, texture and structure of the sediments. Textural analyses, calcium carbonate and radiocarbon dating were performed on selected samples. Grain-size analyses were carried out at the Institut de Ciències del Mar (CSIC) using a settling tube for the coarsegrained $(>50 \mu \mathrm{m})$ fraction and SediGraph 5100 for the silt and clay $(<50 \mu \mathrm{m})$ fractions. For radiometric analysis (i.e. 


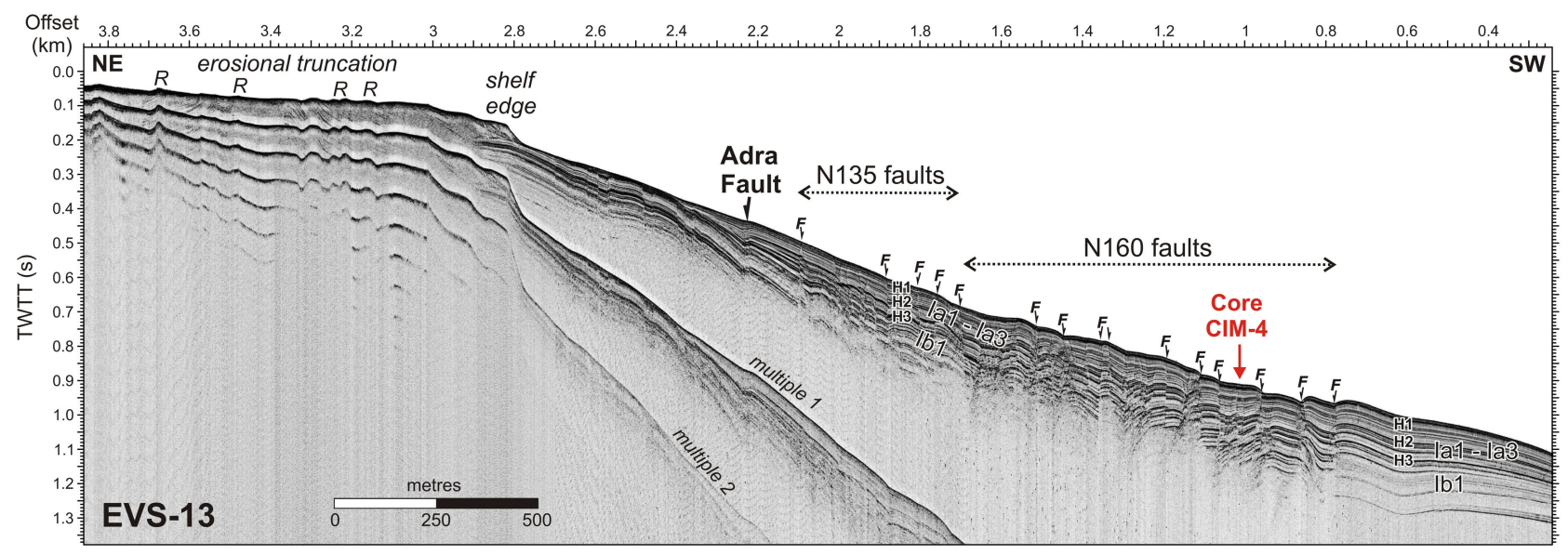

Fig. 4. Regional Sparker profile EVS-13 from the shelf to the middle slope. The Adra Fault and its parallel N135 faults together with the neighbouring N160 faults are imaged. Sediment core CIM-4 is located. Age of horizons are H1: Late Quaternary, H2: Early Quaternary (1.8 Ma), and H3: Late Pliocene (3.6 Ma). Vertical exaggeration at the seafloor 1.5.

${ }^{14} \mathrm{C}$ AMS dating), we hand-picked 6 samples containing 7 and $10 \mathrm{mg}$ of mixed or monospecific planktonic foraminifera with a diameter larger than $250 \mu \mathrm{m}$. Samples were processed and measured at the NOSAMS-WHOI laboratory. The ${ }^{14} \mathrm{C}$ ages of hemipelagic samples were calibrated using the Marine09 curve (Reimer et al., 2009) included in Calib 6.1 software and considering a present-day reservoir age $(\Delta R)$ of $-22 \pm 35{ }^{14} \mathrm{C}$ yr for the Málaga site (Table 1).

\section{Results}

\subsection{Morphology of the Adra shelf and upper slope}

The study area is located to the northeast of the Alboran Basin, extending from $2^{\circ} 48^{\prime} \mathrm{W}$ to $3^{\circ} 08^{\prime} \mathrm{W}$, and from $36^{\circ} 44^{\prime} \mathrm{N}$ to $36^{\circ} 32^{\prime} \mathrm{N}$ (Figs. 2 and 3 ). The shelf drastically narrows from east to west (from 12 to $4 \mathrm{~km}$ ) and has a generally smooth morphology with a gradient less than $1^{\circ}$ (Figs. 3 and 4). On the widest part of the shelf, two NW-SE trending slightly sigmoidal ridges are visible (Sanz et al., 2004) (Fig. 2), corresponding to sedimentary ridges (Fig. 4). Following a NW-SE trend, the offshore continuation of the Balanegra Fault escarpment is clearly recognized (Figs. 2 and 3).

Holocene infralittoral prograding wedges are also identified on the shelf (Figs. 2 and 3). They correspond to narrow (up to $2.5 \mathrm{~km}$ wide) morphosedimentary units which develop seaward from the shoreface and extend to a well-defined break of slope at water depths of 35-40 m (Fernández-Salas et al., 2007). The shelf edge locally depicts a maximum slope of $15^{\circ}$. Incised on the shelf edge (100 m depth), the NESW trending $11.3 \mathrm{~km}$ long Adra Channel obliquely cuts the upper slope and stops around $650 \mathrm{~m}$ depth. At the base of the shelf edge, between $2^{\circ} 56^{\prime} \mathrm{W}$ and $2^{\circ} 52^{\prime} \mathrm{W}$, a cluster of small rounded monticules correspond to coral mounds, first described by Ballesteros et al. (2008) (Fig. 2).

The upper slope is dominated by a large, isolated flattopped circular seamount with very steep slopes $\left(>15^{\circ}\right)$ referred to as the Chella Bank, bounded by irregular volcanic ridges (e.g. Lo Iacono et al., 2008) (Figs. 2 and 3). To the east of the bank, the deeply incised Dalías Tributary Valley System drains from the shelf edge until it intersects the leftlateral Carboneras Fault, which produces a sharp deflection of its channels and gullies (Gràcia et al., 2006; Moreno et al., 2008). To the west of the Chella Bank, numerous linear structures correspond to the morphological expression of fault systems. Most of the faults exhibit steep scarps that affect the seafloor, indicating present-day activity (Figs. 2 and 3). On the swath-bathymetric and slope maps, we identify a N132 trending $18.5 \mathrm{~km}$ long and $\sim 500 \mathrm{~m}$ wide lineation, which corresponds to the surface expression of a fault, which is termed the Adra Fault (Figs. 2, 3 and 4). Parallel to this fault, NW-SE trending narrowly-spaced, short (3-4 km long), rectilinear escarpments are termed the N135 faults. To the south of these structures, we observe a succession of NNW-SSE trending, closely spaced, en echelon short faults (1-3 km long) termed the N160 faults (Figs. 2 and 3).

\subsection{Seismostratigraphy and age of the recentmost sediments}

Seismostratigraphic units have been established on the basis of seismic facies and discontinuities defined in highresolution multichannel seismic profiles from the Carboneras Fault area (Moreno, 2011), which we extrapolated to the Sparker profiles from the Adra margin. The high resolution of our dataset in imaging the Plio-Quaternary succession enabled us to review previously defined units from the Alboran Sea (e.g. Jurado and Comas, 1992) and to identify new 


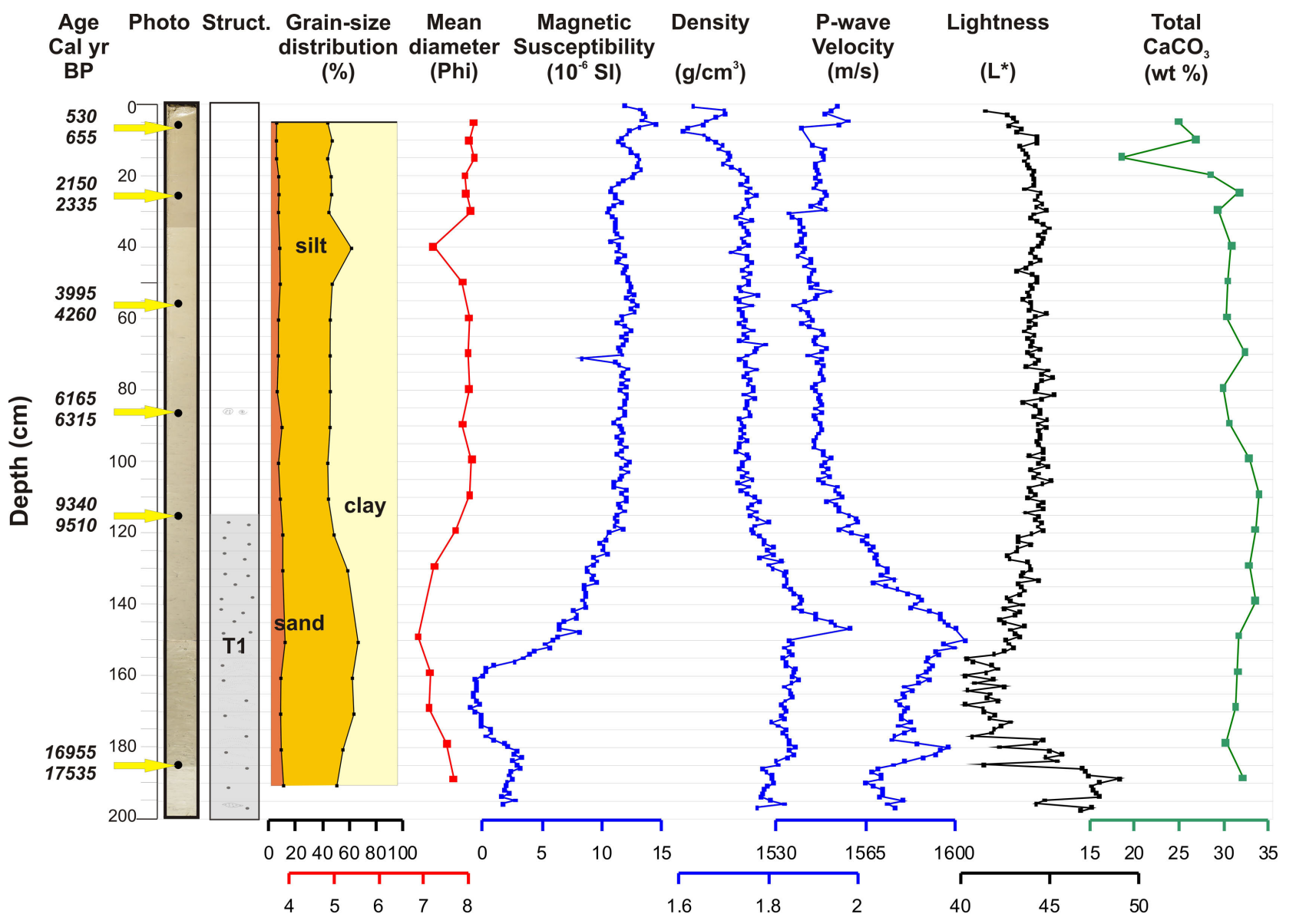

Fig. 5. Image, lithological description, grain-size distribution, mean diameter, magnetic susceptibility, density, P-wave velocity, lightness, total calcium carbonate and calibrated ages of CIM-4 sediment core. T1 refers to a mud-rich turbidite interval.

Table 1. Location of the studied core, radiocarbon AMS data and sample age calibrations based on the Marine09 curve (Reimer et al., 2009) included in Calib 6.1 calibration software.

\begin{tabular}{|c|c|c|c|c|c|c|c|c|c|}
\hline Core \# & $\begin{array}{l}\text { Lat } \\
\left({ }^{\circ} \mathrm{N}\right)\end{array}$ & $\begin{array}{l}\text { Lon } \\
\left({ }^{\circ} \mathrm{W}\right)\end{array}$ & $\begin{array}{r}\text { Water } \\
\text { depth } \\
(\mathrm{m})\end{array}$ & $\begin{array}{r}\text { AMS } \\
\text { lab } \\
\text { reference }\end{array}$ & $\begin{array}{r}\text { Core } \\
\text { depth } \\
(\mathrm{cm})\end{array}$ & $\begin{array}{l}\text { Foraminifera } \\
\text { sampled }\end{array}$ & $\begin{array}{r}\text { Radiocarbon } \\
\text { age } \\
(\mathrm{yr} \mathrm{BP} \pm 1 \sigma)\end{array}$ & $\Delta R^{*}$ & $\begin{array}{r}1 \sigma \\
\text { calibrated age } \\
(\text { Cal yr BP })\end{array}$ \\
\hline CIM-4 & $36^{\circ} 31.55^{\prime}$ & $3^{\circ} 04.37^{\prime}$ & 850 & 60691 & $8.5-10$ & Globorotalia inflata & $1000 \pm 30$ & $-22 \pm 35$ & $530-655$ \\
\hline \multirow{5}{*}{\multicolumn{2}{|c|}{ Adra-Almería Margin }} & & & 60692 & $28.5-30$ & Globorotalia inflata & $2560 \pm 45$ & $-22 \pm 35$ & $2150-2335$ \\
\hline & & & & 60693 & $58.5-60$ & Globorotalia inflata & $4070 \pm 40$ & $-22 \pm 35$ & $3995-4260$ \\
\hline & & & & 60694 & $88.5-90$ & Globorotalia inflata & $5800 \pm 40$ & $-22 \pm 35$ & $6165-6315$ \\
\hline & & & & 60695 & $117-118.5$ & Neogloboquadrina pachyderma & $8730 \pm 45$ & $-22 \pm 35$ & $9340-9510$ \\
\hline & & & & 60696 & $186-187.5$ & Globigerina bulloides & $14550 \pm 95$ & $-22 \pm 35$ & $16955-17535$ \\
\hline
\end{tabular}

* Local reservoir correction $(\Delta R)$ for the Málaga site based on Stuiver and Reimer (1993).

sub-units and seismic horizons in the study area (Fig. 4). The Sparker profiles, with a maximum penetration of up to $400 \mathrm{~ms}$ TWTT display an alternation of sequences of (a) continuous, high-amplitude parallel-bedded well-stratified seismic facies and (b) semi-transparent seismic facies with moderate-low amplitudes. We distinguished 4 seismostratigraphic units, from top to bottom, units Ia1, Ia2, Ia3 and Ib1, separated by horizons $\mathrm{H} 1$ to H3, respectively (Fig. 4). Based on the correlation with the horizons previously defined in the Almería margin (Moreno, 2011), the ages of the Adra seismic horizons are Late Quaternary for H1, Early Quaternary (base of Calabrian stage, 1.8 Ma) for $\mathrm{H} 2$, and Late Pliocene (3.6 Ma) for $\mathrm{H} 3$.

Sediment core CIM-4, for which age control was established, was collected within the N160 fault array system, which is crossed by profile EVS-13 (Figs. 3 and 4). Along 
this profile, the uppermost sedimentary units Ia1-Ia3 can be followed upslope north of the Adra Fault, where it onlaps the lower unit Ib1 (Fig. 4). Sampled sediments consisted in olive to olive-grey silty clay (Holocene section) to clayey silt (early Holocene-Late Pleistocene section), with an average mean diameter of 7.8 phi. Their composition is mainly terrigenous with an average calcium carbonate content of $30 \%$ (Fig. 5). Physical properties (magnetic susceptibility, density, Pwave-velocity and lightness) show fairly constant values in the upper half of the core. By contrast, from $115 \mathrm{~cm}$ depth to the base of the core, density and Pwavevelocity values slightly increase, whereas magnetic susceptibility and lightness decrease. Texture, sedimentary structures and physical properties allow us to distinguish two main facies: hemipelagite and turbidite (Fig. 5). From top to bottom, there is a $115 \mathrm{~cm}$ thick hemipelagic interval interrupted by a thin $10 \mathrm{~cm}$ silty layer at $40 \mathrm{~cm}$ depth below the seafloor. From $115 \mathrm{~cm}$ to the base of the core, an $85 \mathrm{~cm}$ thick dark interval (T1) characterized by thin irregular muddy layers and coarse silty lenses, corresponds to a mud-rich turbidite (Fig. 5). The age model of core CIM-4 is based on 5 radiometric dates, assuming that the sedimentation rate is constant between contiguous dated samples above the turbidite $\mathrm{T} 1$, the age of which is older than $9510 \mathrm{Cal} \mathrm{yr} \mathrm{BP}$. The sixth available date (16955-17535 Cal yr BP) corresponds to an older value, probably related to reworked material within turbidite T1. Earthquakes may constitute a likely trigger mechanism of these gravity flow deposits in the NE Alboran Sea. However, without a synchronicity test based on widespread and coeval mass-transport deposits to demonstrate that these are simultaneously triggered by an earthquake, other processes cannot be ruled out (e.g. Gràcia et al., 2010). Calibrated dates reveal Holocene age with an average sedimentation rate of $\sim 12.3 \mathrm{~cm} \mathrm{kyr}^{-1}$ (Fig. 5). The youngest age is $530-655 \mathrm{Cal}$ yr BP at $5 \mathrm{~cm}$ depth with the result that we can assume that the age of the seafloor is present-day (Table 1). This is important for the correlation with the Sparker profiles where it is possible to ascertain whether faults rupture the seafloor (Figs. 4 and 6).

\subsection{High-resolution seismic imaging of the Adra Fault}

Analysis of the acoustic and seismic data distinguishes two main parallel segments along the Adra Fault: the western and eastern segments (Fig. 2). Between the segments, there is a $250 \mathrm{~m}$ wide left-stepping offset. The succession of six highresolution Sparker profiles across the Adra Fault illustrates how its shallow structure varies along-strike (Figs. 4 and 6).

The western segment is $9.2 \mathrm{~km}$ long and trends N130. At its NW end, stratified unit Ib1 (Pliocene) is folded by a wide, open anticline (Fig. 6a, profile EVS-11). The Adra Fault is sub-vertical and cuts the high-amplitude anticline deforming units Ia3 and Ia2, although the fault does not seem to reach the seafloor. In the middle of the segment (Fig. 6b, profile EVS-12), an uplifted narrowly folded block of transparent facies marks the location of the Adra Fault. This fault separates zones of different stratigraphy belonging to unit Ib1, forming what we interpret as a pressure ridge. Onlapping this ridge is a wedge of stratified facies from the top of unit Ib1 and units Ia1 to Ia3. They are slightly folded and cut by tightly spaced sub-vertical faults reaching the surface. The geometry of the central part of this segment also coincides with a $20-25 \mathrm{~m}$ high upwarp of the seafloor, as observed between offsets 0.4 and $0.55 \mathrm{~km}$. The southern part of this segment (Figs. 4 and 6c profile EVS-13) depicts a $25 \mathrm{~m}$ wide fault zone with a horizontal seabed. At depth, two sub-vertical discontinuities (faults) are identified and interpreted as a negative flower structure, affecting unit $\mathrm{Ib}$ up to the seafloor.

The eastern segment of the Adra Fault is $9.4 \mathrm{~km}$ long and trends N134. The first profile across this segment (Fig. 6d, profile EVS-14) shows a neat displacement of the whole sedimentary sequence with the fault dipping $70^{\circ}-80^{\circ}$ to the $\mathrm{NE}$, suggesting a normal fault geometry. On the hanging wall, narrowly spaced sub-vertical faults dipping to the SW are also identified. A subdued upwarp $(2 \mathrm{~m})$ is detected at the seafloor. At the segment centre (Fig. 6e, profile EVS-15), the Adra Fault dips slightly to the NE and vertically offsets a sequence, which is narrowly folded on the hanging wall and high-amplitude folded on the footwall. Towards the south (Fig. 6f, profile EVS-16), the Adra Fault is sub-vertical, dipping slightly to the SW. On its hanging wall, unit Ia develops a small sedimentary wedge above horizon H3 (Late Pleistocene age). The segment ends bounding one of the ridges located west of the Chella Bank, as observed on the bathymetric map (Fig. 2). In this area, the Adra Fault is not visible on the Sparker profiles (Fig. 3, EVS-17 and EVS-18) since the volcanic nature of the Chella Bank ridges masks the fault structure at depth.

\section{Discussion}

\subsection{Kinematics of the Adra Fault: relationship with structures onshore}

The new data shows that the Adra Fault is active given that it affects all the sedimentary sequences, cutting the uppermost units, which based on dates from sediment core CIM-4 are of late Holocene age (Fig. 5). According to the bathymetric and high-resolution Sparker seismic profiles, the superficial expression of the Adra Fault zone mainly consists of an upwarped, elongated narrow area bounded by steeply dipping faults at depth. The shallow structure of the western segment consists of a series of upward-splaying sub-vertical faults defining positive and negative flower structures in cross section (Fig. 6). These high-angle faults probably coalesce at greater depths and constitute part of a single Adra Fault. Our data shows a variation in the three-dimensional structural geometry along the strike of the fault, analogous to those that 

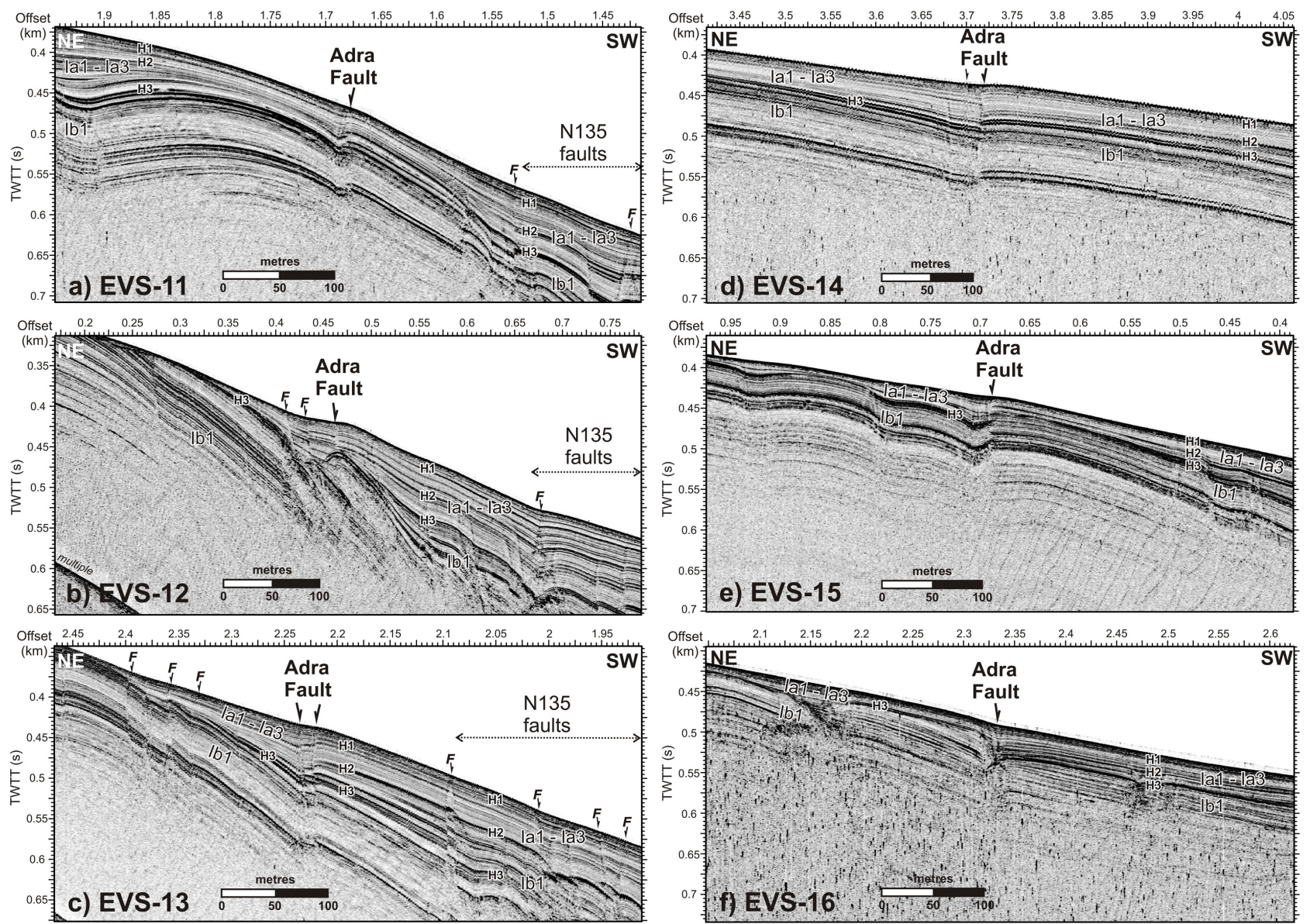

Fig. 6. Succession of Sparker profiles EVS-11 to EVS-16 across the Adra Fault. Age of horizons are H1: Late Quaternary, H2: Early Quaternary (1.8 Ma), and H3: Late Pliocene (3.6 Ma). Vertical exaggeration at the seafloor $\sim 1.5$.

have been documented in strike-slip faults exposed on land (Sylvester et al., 1988). In addition, along its eastern segment, the Adra Fault also provides evidence of a vertical component, which is of normal movement and dips strongly $\left(70^{\circ}-80^{\circ}\right)$ towards the NE (Fig. 6 ).

The regional stress field derived from earthquake focalmechanism inversions in the Alboran Sea and southeast Spain suggests a local shortening along an approximate NNW-SSE axis (Stich et al., 2006). This direction also coincides with the most compressive horizontal stress orientation $\left(\mathrm{Sh}_{\mathrm{MAX}}\right)$ and regime predicted by neotectonic modelling based on thin-sheet finite elements and geodetic measurements (e.g. Jiménez-Munt and Negredo, 2003; Stich et al., 2006). Considering the shortening axis, we assume the strain regime of the Adra Fault, which would move as normal with a right-lateral component. This may be compatible with the model of block tectonics presented by MartínezDíaz and Hernández-Henrile (2006) to account for the active structures of the SE Iberian margin. In this model, predominantly extensional structures such as Loma del Viento, Punta Entinas and Balanegra faults (Fig. 2) accommodate the deformation produced by squeezing the wedge located between the right-lateral Corredor de las Alpujarras Fault Zone and the left-lateral Carboneras Fault (Fig. 7). The different mechanical behaviour between these fault zones would induce a westward tectonic escape and the generation of NW-SE trending normal-dextral faults, such as the Loma del Viento Fault on land (Martínez-Díaz and Hernández-Henrile, 2006) and the Adra Fault offshore. Preliminary geodetic data from a local GPS network are also in line with this kinematics (Khazaradze et al., 2010).

\subsection{Seismic parameters of the Adra Fault: link with the 1910 Earthquake}

Present-day seismicity in the southeastern Iberian margin shows swarms of small to moderate magnitude $\left(M_{\mathrm{w}}<5\right)$, shallow $(<10 \mathrm{~km})$ earthquakes (Stich et al., 2001, 2003a, 2006, 2010) which are mainly concentrated to the north and east/southeast of the Chella Bank (Fig. 7). As regards the Adra Fault, only few epicentres are located along its trace. However, this does not mean that we should attribute little seismological hazard to this fault. To evaluate 


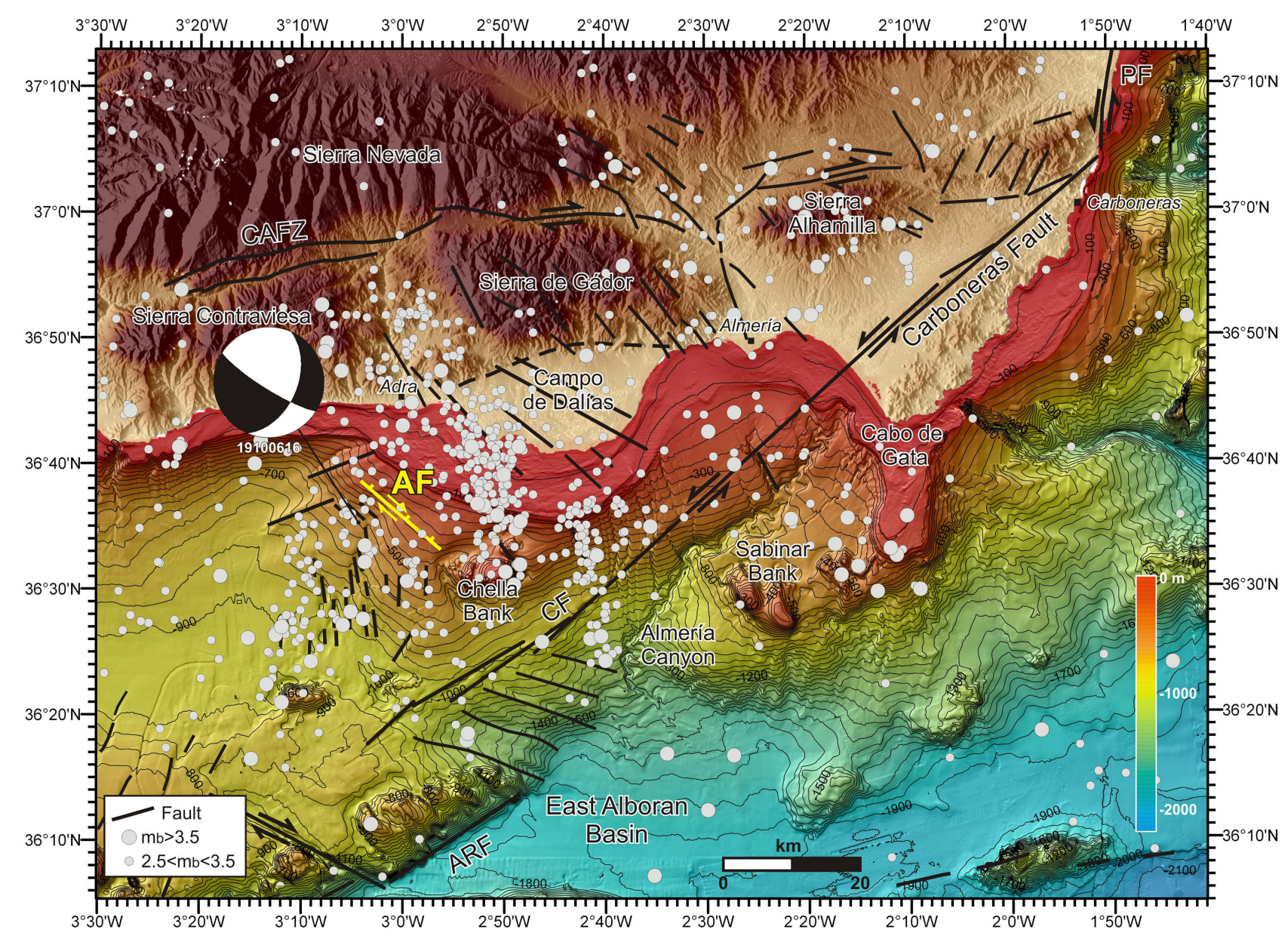

Fig. 7. Topographic and colour-shaded bathymetric map (isobaths every $50 \mathrm{~m}$ ) of the Almería-Adra margin. Seismicity from the Instituto Geográfico Nacional catalogue for the period between 1965 and 2010 is depicted (I.G.N., 2010). Grey dots correspond to epicentres of earthquakes for different magnitudes. Main active faults onshore and offshore are located in black. The normal-dextral Adra Fault is depicted in yellow. Moment tensor solution obtained for the 1910 Adra Earthquake is also located (Stich et al., 2003b). CAFZ: Corredor de las Alpujarras Fault Zone; CF: Carboneras Fault; PF: Palomares Fault; ARF: Adra Ridge Fault.

the seismic potential of the Adra Fault, we measured the fault dimensions (length, strike, and dip) of the segments and of the overall fault, we estimated their minimum and maximum seismogenic depths, and we calculated their width and surface area. Considering maximum segment lengths of $18.5 \pm 0.2 \mathrm{~km}$ for the whole Adra Fault and $9.4 \pm 0.2 \mathrm{~km}$ for the longest eastern segment, a sub-vertical fault dip at $80^{\circ} \pm 10^{\circ}$, a rake of $-135^{\circ}$, and a maximum seismogenic depth of $15 \mathrm{~km}$, we obtained maximum rupture surfaces of $281.78 \mathrm{~km}^{2}$ and $143.18 \mathrm{~km}^{2}$, respectively. To obtain seismic parameters, we used the empirical relationship of Wells and Coppersmith (1994) for strike-slip faults relating the surface area with the maximum magnitude, as $M_{\mathrm{w}}=4.07+0.98 \times$ $\log A$, where $A$ is the rupture area. The maximum values obtained are $M_{\mathrm{w}}=6.47 \pm 0.24$ for the total length of the Adra Fault and $M_{\mathrm{w}}=6.18 \pm 0.24$ for the eastern segment. These fault parametres are of considerable interest to the seismic hazard assessment models of the Iberian Peninsula (e.g. Nemser et al., 2010).

The 1910 Earthquake event was recorded by the first operating Spanish stations as well as by observatories outside Spain. Although several larger or comparable events occurred in the Iberian Peninsula during historical times, the 1910 Adra event is still the largest instrumentallyrecorded crustal earthquake in Spain (Stich et al., 2003b). The mainshock occurred on 16 June 1910, causing destruction corresponding to $\mathrm{I}_{0}=\mathrm{VIII}$ MSK in the small town of Adra (Vidal, 1986), and was felt with $\mathrm{I}_{0}=\mathrm{VI}$ in Almería, Granada and Málaga, up to $100 \mathrm{~km}$ away from the epicentre. The earthquake was also noticed by boats offshore Adra indicating an epicentre in the northeastern Alboran Sea. Six days later, numerous aftershocks followed a major $\mathrm{I}_{0}=\mathrm{VII}$ MSK earthquake (Stich et al., 2003b). These authors reexamined and modelled the analogue recordings applying modern techniques to estimate the source parameters of the 
event. The best fitting moment tensor solution corresponds to a seismic moment $M_{0}=1.50 \times 10^{18} \mathrm{Nm}$ and a moment magnitude of $M_{\mathrm{w}}=6.1$ oblique strike-slip event at $16 \mathrm{~km}$ depth, although the depth resolution for this event is low due to the small number of recordings. In agreement with the available neotectonic and seismotectonic data, the preferred faulting solution strikes $122^{\circ}$, dips $80^{\circ}$ and rakes $-137^{\circ}$ (Stich et al., 2003b). The deconvolution of the aftershock yields the relative source time function, which indicates a total rupture time of $4.5 \mathrm{~s}$, corresponding to estimates for mainshock rupture length of $12 \mathrm{~km}$.

Linking historical earthquakes with fault sources is not an easy task, since detailed information about the epicentre is sparse or null and the coseismic surface ruptures accompanying an historical earthquake may not be preserved (Ambraseys, 1975). This is even more complex in marine areas, where only in few cases has the fault source been successfully found (e.g. Elias et al., 2007). Considering the macroseismic intensity pattern (Vidal, 1986) and the epicentre relocation (Stich et al., 2003b), the Adra event (Figs. 1 and 7) falls relatively close (given location uncertainties) to the submerged trace of the Adra Fault as mapped in the present study (Fig. 7), discarding the sources located onshore (i.e. Balanegra Fault). In addition, this is the only fault identified near the epicentral location with large enough dimensions capable of generating an earthquake of this magnitude. Finally, fault seismic parameters of the Adra Fault are consistent with the moment tensor calculations (Stich et al., 2003b) with respect to the preferred NW-SE trending fault plane, fault plane dimension and normal-dextral solution. All this suggests that the Adra Fault is the most plausible source of the $M_{\mathrm{w}}=6.1$ 1910 Adra Earthquake event.

\section{Conclusions}

1. High-resolution acoustic and seismic data from the Almería margin together with ${ }^{14} \mathrm{C}$ dating from a sediment core of the area allowed us to identify and characterize a new fault in the NE Alboran Sea, which we termed the Adra Fault. The superficial expression of the Adra Fault consists of an upwarped narrow deformation zone bounded by sub-vertical faults that trend N130 and extend for more than $18 \mathrm{~km}$ ending in a volcanic ridge of the Chella Bank. A narrow stepover separates the parallel western and eastern segments of the Adra Fault.

2. The Adra Fault cuts and folds the most recent sedimentary units of late Holocene age, indicating that it corresponds to an active structure. Considering the NNW-SSE regional shortening axis between Eurasia and Africa, the Adra Fault may have a normal-dextral component as the faults onshore Campo de Dalías (i.e. Loma del Viento Fault). These structures may be consistent with the model of block tectonic escape suggested by Martínez-Díaz and Hernández Enrile (2006).
3. Despite the low seismic activity recorded along the Adra Fault trace, our data suggest that this structure is a potential source of large magnitude (up to $M_{\mathrm{w}} \sim 6.5$ ) events and it is a very likely source of the 1910 Adra Earthquake. This is corroborated by the proximity of the Adra Fault to the earthquake epicentre and by the good fit between the fault parameters and the fault solution obtained from the seismic moment tensor. Seismic and tsunami hazard in the southeast Iberia and African margins would significantly increase if offshore structures such as the Adra Fault are considered.

Acknowledgements. The authors acknowledge the support of the Spanish Ministry of Science and Innovation (MICINN) through National Projects IMPULS (REN2003-05996MAR), EVENT (CGL2006-12861-C02-02) and SHAKE (CGL2011-30005C02-02); Acciones Complementarias EVENT-SHELF (CTM 2008-03346-E/MAR) and SPARKER (CTM 2008-03208-E/MAR) and the ESF TopoEurope TOPOMED project (CGL2008-03474E/BTE). We thank the captain, crew, scientific party and technical staff of the UTM-CSIC on board the Spanish R/V "Hesperides" and R/V "García del Cid" during the IMPULS and EVENT-SHELF cruises, respectively. We thank Fabrizio Pepe (Univ. Palermo) for his assistance in using the Geotrace software. We thank guest editor Hans Nelson, Carlos Marín Lechado and an anonymous referee for constructive comments and reviews. This work has been carried out within Grup de Recerca de la Generalitat de Catalunya B-CSI (2009 SGR 146).

Edited by: H. Nelson

Reviewed by: C. Marin Lechado and one anonymous referee

\section{References}

Alfaro, P., Delgado, J., Estévez, A., Soria, J. M., and Yébenes, A.: Onshore and offshore compressional tectonics in the eastern Betic Cordillera (SE Spain), Mar. Geol., 186, 337-349, 2002.

Ambraseys, N. N.: Studies in historical seismicity and tectonics, in: Geodynamics of Today, Royal Society of London, 9-16, 1975.

Argus, D. F., Gordon, R. G., DeMets, C., and Stein, S.: Closure of the Africa- Eurasia-North America plate motion circuit and tectonics of the Gloria fault, J. Geophys. Res., 94, 5585-5602, 1989.

Ballesteros, M., Rivera, J., Muñoz, A., Muñoz-Martín, A., Acosta, J., Carbó, A., and Uchupi, E.: Alboran Basin, southern Spain - Part II: Neogene tectonic implications for the orogenic float model, Mar. Petr. Geol. 25, 75-101, 2008.

Bartolome, R., Lo Iacono, C., and Gràcia, E.: Multiscale seismic imaging of active faults at sea, Sea-Technol., 50, 10-14, 2009.

Bousquet, J. C.: Quaternary strike-slip faults in southeastern Spain, Tectonophysics, 52, 277-286, 1979.

Buforn, E., Sanz de Galdeano, C., and Udías, A.: Seismotectonics of Ibero-Maghrebian region, Tectonophysics, 248, 247-261, 1995.

Buforn, E., Bezzeghoud, M., Udías, A., and Pro, C.: Seismic sources on the Iberia-African Plate boundary and their Tectonic Implications, Pure Appl. Geophys., 161, 623-646, 2004. 
Comas, M. C., Platt, J. P., Soto, J. I., and Watts, A. B.: The origin and tectonic history of the Alboran Basin: insights from leg 161 results, in: Proc. ODP, Sci. Res., 161, Ocean Drilling Program, College Station, USA, 555-580, 1999.

DeMets, C., Gordon, R. G., and Argus, D. F.: Geologically current plate motions, Geophys. J. Int., 181, 1-80, 2010

Elias, A., Tapponier, P., Singh, S. C., King, G. C. P., Briais, A., Daëron, M., Carton, H., Sursock, A., Jacques, E., Jomaa, R., and Klinger, Y.: Active thrusting offshore Mount Lebanon: Source of the tsunamigenic A.D. 551 Beirut-Tripoli earthquake, Geology, 35, 755-758, 2007.

Fernández-Salas, L. M., Dabrio, C. J., Goy, J. L., Díaz del Río, V., Zazo, C., Lobo, F. J., Sanz, J. L., and Lario, J.: Land-sea correlation between late Holocene coastal and infralittoral deposits in the SE Iberian Peninsula (Western Mediterranean), Geomorphology, 104, 4-11, 2009.

Gràcia, E., Pallàs, R., Soto, J. I., Comas, M., Moreno, X., Masana, E., Santanach, P., Diez, S., García, M., and Dañobeitia, J. J.: Active faulting offshore SE Spain (Alboran Sea): Implications for earthquake hazard assessment in the Southern Iberian Margin, Earth Planet. Sci. Lett., 241, 734-749, 2006.

Gràcia, E., Vizcaino, A., Escutia, C., Asioli, A., Rodés, A., Pallàs, R., Garcia-Orellana, J., Lebreiro, S., and Goldfinger, C.: Holocene earthquake record offshore Portugal (SW Iberia): Testing turbidite paleoseismology in a slow-convergence margin, Quat. Sci. Rev., 29, 1156-1172, 2010.

I.G.N.: Catálogo sísmico nacional hasta el 2010, Instituto Geográfico Nacional, Madrid, http://www.ign.es/ign/layoutIn/ sismoFormularioCatalogo.do, 2010.

Jiménez-Munt, I. and Negredo, A. M.: Neotectonic modelling of the western part of the Africa-Eurasia plate boundary: from the MidAtlantic ridge to Algeria, Earth Planet. Sci. Lett., 205, 257-271, 2003.

Jurado, M. J. and Comas, M. C.: Well log interpretation and seismic character of the Cenozoic sequence in the northern Alboran Sea, Geo-Marine Lett., 12, 129-136, 1992.

Khazaradze, G., Moreno, X., Asensio, E., and Masana, E.: Resultados preliminares de actividad de la falla de Carboneras (Betica Orientales) mediante GPS, in: Contribución de la Geología al Análisis de la Peligrosidad Sísmica, 205, Sigüenza (Guadalajara, España), 2010.

Keller, J. V. A., Hall, S. H., Dart, C. J., and McClay, K. R.: The geometry and evolution of a transpressional strike-slip system: the Carboneras fault, SE Spain, J. Geol. Soc. London, 152, 339$351,1995$.

Lo Iacono, C., Gràcia, E., Diez, S., Bozzano, G., Moreno, X., Dañobeitia, J., and Alonso, B.: Seafloor characterization and backscatter variability of the Almería Margin (Alboran Sea, SW Mediterranean) based on high-resolution acoustic data, Mar. Geol., 250, 1-18, 2008.

Marín-Lechado, C., Galindo-Zaldívar, J., Rodríguez-Fernández, L. R., Serrano, I., and Pedrera, A.: Active faults, seismicity and stresses in an internal boundary of a tectonic arc (Campo de Dalías and Níjar, southeastern Betic Cordilleras, Spain), Tectonophysics, 396, 81-96, 2005.

Marín-Lechado, C., Galindo-Zaldívar, J., Rodríguez-Fernández, L. R., and Pedrera, A.: Mountain front development by folding and crustal thickening in the internal zone of the Betic CordilleraAlboran Sea Boundary, Pure Appl. Geophys., 164, 1-21, 2007.
Martínez-Díaz, J. J.: Neotectónica y tectónica activa del sector centro-occidental de Murcia y Sur de Almería, Cordillera Bética (España), Ph.D. thesis, Universidad Complutense de Madrid, 466 pp., 1998.

Martínez-Díaz, J. J. and Hernández-Enrile, J. L.: Neotectonics and morphotectonics of the southern Almería region (Betic Cordillera-Spain) kinematics implications, Int. J. Earth. Sci., 93, 189-206, 2004.

Martínez-Díaz, J. J., Masana, E., Hernández-Enrile, J. L., and Santanach, P.: Evidence for coseismic events of recurrent prehistoric deformation along the Alhama de Murcia Fault, southeastern Spain, Acta Geol. Hispanica, 36, 315-327, 2001.

Masana, E., Martínez-Díaz, J. J., Hernández-Enrile, J. L., and Santanach, P.: The Alhama de Murcia fault (SE Spain), a seismogenic fault in a diffuse plate boundary: Seismotectonic implications for the Ibero-Magrebian region, J. Geophys. Res., 109, 1-17, 2004.

Masana, E., Pallàs, R., Perea, H., Ortuño, M., Martínez-Díaz, J. J., García-Meléndez, E., and Santanach, P.: Large Holocene morphogenic earthquakes along the Albox Fault, Betic Cordillera, Spain, J. Geodyn., 40, 119-133, 2005.

McCalpin, J.: Paleoseismology, Academic Press cop., San Diego, 588 pp., 1996.

MEDIMAP Group, Loubrieu, B., and Mascle, J.: Morphobathymetry of the Mediterranean Sea, Map CIESM edition, 2008.

Moreno, X.: Neotectonic and Paleoseismic onshore-offshore integrated study of the Carboneras Fault (Eastern Betics, SE Iberia), Ph.D. thesis, Universitat de Barcelona, 365 pp., 2011.

Moreno, X., Masana, E., Gràcia, E., Bartolomé, R., and PiquéSerra, O.: Estudio paleosismológico de la Falla de Carboneras: Evidencias tierra-mar de actividad tectónica reciente, GeoTemas, 10, 1035-1038, 2008.

Muñoz, A., Ballesteros, M., Montoya, I., Rivera, J., Acosta, J., and Uchupi, E.: Alboran Basin, southern Spain-Part I: Geomorphology, Mar. Petr. Geol. 25, 59-73, 2008.

Nemser, E. S., García-Mayordomo, J., Cabral, J., Fonseca, J. F. B. D., Martínez-Díaz, J. J., Vilanova, S., and 2010 Working Group on Iberian Seismogenic Sources: Compilation of parameterized seismogenic sources in Iberia for the SHARE European-scale seismic source model, in: Contribución de la geología al análisis de la peligrosidad sísmica, 201-204, 2010.

Pantosti, D. and Yeats, R. S.: Paleoseismology of great earthquakes of the late Holocene, Ann. Geofis., 36, 237-257, 1993.

Pedrera, A., Marín-Lechado, C., Stich, D., Ruiz-Constán, A., Galindo-Zaldívar, J., Rey-Moral, C., and Mancilla, F. L.: Nucleation, linkage and active propagation of a segmented Quaternary normal-dextral fault: the Loma del Viento fault (Campo de Dalías, Eastern Betic Cordillera, SE Spain), Tectonophysics, 522-523, 208-217, 2012.

Peláez, J. A. and López Casado, C.: Seismic hazard estimate at the Iberian Peninsula, Pure Appl. Geophys., 159, 2699-2713, 2002.

Perea, H., Gràcia, E., Alfaro, P., Bartolomé, R., Lo Iacono, C., Moreno, X., Masana, E., and EVENT-SHELF Team: Quaternary active tectonic structures in the offshore Bajo Segura basin (SE Iberian Peninsula - Mediterranean Sea), Nat. Hazards Earth Syst. Sci., in press, 2012.

Reimer, P. J., Baillie, M. G. L., Bard, E., Bayliss, A., Beck, J. W., Blackwell, P. G., Bronk Ramsey, C., Buck, C. E., Burr, G., Ed- 
wards, R. L., Friedrich, M., Grootes, P. M., Guilderson, T. P., Hajdas, I., Heaton, T. J., Hogg, A. G., Hughen, K. A., Kaiser, K. F., Kromer, B., McCormac, F. G., Manning, S. W., Reimer, R. W., Richards, D. A., Southon, J., Turney, C. S. M., van der Plicht, J., and Weyhenmeyer, C.: IntCa109 and Marine09 Radiocarbon Age Calibration Curves, 0-50000 Years cal BP, Radiocarbon, 51, 1111-1150, 2009.

Rodríguez-Fernández, J. and Martín-Penela, J.: Neogene evolution of the Campo de Dalías and surrounding offshore areas (Northeastern Alboran Sea), Geodin. Acta, 6, 255-270, 1993.

Sanz, J. L., Tello, O., Hermida, N., Fernández-Salas, L. M., González, J. L., Pastor, E., Bécares, M. A., Cubero, P., Godoy, D., Alcalá, C., Contreras, D., Frias, A.J., Ramos, M., Torres, A., Ubiedo, J. M., Alfageme, V. M., Carreño, F., Pascual, L., Pérez, J. I., Redondo, B. C., Velasco, D., and González, F.: Aguadulce a Balanegra (Almería), Serie cartográfica Estudio de la Plataforma continental Española, Ministerio de Agricultura, Pesca y Alimentación, Secretaría General de Pesca Marítima - Instituto Español de Oceanografía, Maps MC052 and MC053, 2004.

Sanz de Galdeano, C.: Geologic evolution of the Betic Cordilleras in the Western Mediterranean, Miocene to present, Tectonophysics, 172, 107-119, 1990.

Silva, P. G., Goy, J. L., Somoza, L., Zazo, C., and Bardají, T.: Landscape response to strike-slip faulting linked to collisional settings: Quaternary tectonics and basin formation in the Eastern Betics, southeastern Spain, Tectonophysics, 224, 289-303, 1993.

Sylvester, A. G.: Strike-slip faults, Geol. Soc. Am. Bull., 100, 16661703, 1988.

Stich, D., Alguacil, G., and Morales, J.: The relative locations of multiplets in the vicinity of the Western Almería (southern Spain) earthquake series of 1993-1994, Geophys. J. Int., 146, 801-812, 2001.
Stich, D., Ammon, C. J., and Morales, J.: Moment tensor solutions for small and moderate earthquakes in the Ibero-Maghreb region, J. Geophys. Res., 108, 2148-2168, 2003a.

Stich, D., Batlló, J., Morales, J., Macià, R., and Dineva, S.: Source parameters of the $M_{\mathrm{W}}=6.11910$ Adra earthquake (southern Spain), Geophys. J. Int., 155, 539-546, 2003 b.

Stich, D., Serpelloni, E., Mancilla, F., and Morales, J.: Kinematics of the Iberia-Maghreb plate contact from seismic moment tensors and GPS observations, Tectonophysics, 426, 295-317, 2006.

Stich, D., Martín, R., and Morales, J.: Moment tensor inversion for Iberia-Maghreb earthquakes 2005-2008, Tectonophysics, 483, 390-398, 2010.

Stuiver, M. and Reimer, P. J.: Extended ${ }^{14} \mathrm{C}$ data base and revised CALIB $3.0{ }^{14} \mathrm{C}$ age calibration program, Radiocarbon, 35, 215230, 1993.

Vidal, F.: Sismotectónica de la región de las Béticas-Mar de Alboran, $\mathrm{PhD}$ Thesis, University of Granada, Granada, 450 pp., 1986.

Wallace, R. E.: Active faults, paleoseismology and earthquake hazards in the western United States, in: Earthquake prediction: An international review, Am. Geophys. Union, Washington, USA, 209-216, 1981.

Wells, D. L. and Coppersmith, K. J.: New empirical relationships among magnitude, rupture length, rupture width, and surface displacement, Bull. Seism. Soc. Am., 84, 974-1002, 1994.

Zazo, C., Goy, J. L., Dabrio, C. J., Bardají, T., Hillarie-Marcel, C., Ghaleb, B., González-Delgado, J. A., and Soler, V.: Pleistocene raised marine terraces of the Spanish Mediterranean and Atlantic coast: records of coastal uplift, sea-level highstands and climate changes, Mar. Geol., 194, 103-133, 2003. 